\title{
Relationship Model among Learning Environment, Learning Motivation, and Self-Regulated Learning
}

\author{
Dorothea Wahyu Ariani ${ }^{1}$ \\ ${ }^{1}$ Dept. of Management of Economics Faculty, Maranatha Christian University, Bandung, Indonesia \\ Correspondence: Dorothea Wahyu Ariani, Dept. of Management of Economics Faculty, Maranatha Christian \\ University, Jalan Prof. Drg. Surya Sumantri no. 65, Bandung 40164 Indonesia. E-mail: ariani1338@gmail.com, \\ dwariani@gmail.com
}

Received: May 23, 2017

doi:10.5539/ass.v13n9p63
Accepted: July 9, $2017 \quad$ Online Published: August 25, 2017

URL: https://doi.org/10.5539/ass.v13n9p63

\begin{abstract}
This study applies social capital theory, motivation theory, and systems theories to examine the role of the learning environment and motivation in learning to encourage self-regulation in learning especially effort regulation. This study examines the relationship among learning environment (i.e., student cohesiveness, teacher support, involvement, investigation, task orientation, cooperation, and equity), learning motivation (i.e., learning goal orientation, task value, and self-efficacy), and self-regulated learning in effort regulation. This study also examines the mediating role of learning motivation on relation between learning environment and self-regulation in learning effort. Respondents were 307 students of undergraduate program on business, management, and economics in Yogyakarta and Bandung, Indonesia. Self-report questionnaires were administered to respondents during their regular class periods. Results revealed that students' perception of learning environment on all dimensions were significantly related to learning motivation and self-regulation in effort regulation. Students' perception of learning environment especially task orientation dimension was significantly influenced on three dimensions of learning motivation. The result of this study also indicated that learning goal orientation and self-efficacy are the mediating variables in the relationship model. These results supported many of the hypothesized relationships. Further explanations are discussed regarding both the expected and unexpected outcomes.
\end{abstract}

Keywords: learning environment, learning goal orientation, task value, self-efficacy, self-regulation in effort regulation

\section{Introduction}

Over the years research has consistently shown that the quality of the classroom environment in schools is an important determinant in student learning. Students will learn better when they perceive the environment in a positive way. In general, a positive perception of the classroom environment can improve students' learning motivation. Urdan and Schoenfelder (2006) states that in order to encourage students' learning motivation needed attention to the essential characteristics of the classroom learning environment that may affect students' learning motivation.

Importance of learning motivation has been widely known. Besides believed to be the primary impetus to start learning, motivation is also a force to study, as the central to student learning, and as the most powerful determinants of students' success in school. Research on students' motivation is important because motivation significantly influences learning in school. In addition, the motivation has been identified as one important predictor of learning. Motivation in learning is a consistent variable. Furthermore, students' learning motivation and self-regulation are also important for students' academic success (Zimmerman, 2000; Lichtinger \& Kaplan, 2015). Motivation is known as a factor close to personal characteristics such as personality. However Urdan and Schoenfelder (2006) showed that the learning motivation is multiply determined and reflect the complex interaction of a number of personal and situational factors.

According to previous researchers, self-regulation powerfully influences academic achievement (Pintrich \& De Groot, 1990; Zimmeran, 1990; Clearly \& Zimmerman, 2004). Furthermore, one of the of self-regulation process is goal setting and strategic processes that is affected of motivational construct such as self-efficacy, goal orientation, task value, and control beliefs (Dunn et al., 2012). Zimmerman (1994) stated that classrooms' 
characteristic plays an important role in facilitating self-regulated learning. Learning in the classroom can influence the motivational goals that is used by students in learning such as self-regulated learning (Ames, 1992; Maehr \& Midgley, 1991).

Furthermore, Zimmerman (2008) stated that the influence of the factors driving and inhibiting class in students' self-regulated learning is important and should be studied further. According to Schunk and Zimmerman (2007), students' social environment can influence the affective domain and reviews their behaviors. Teachers are an integral component in the classroom environment can inspire students to create a favorable classroom environment that students can feel more personally efficacious and motivated, so they will work hard to be successful. This study took up suggestion from Zimmerman (2008) by investigating psychosocial aspects of learning environments and their influence on students' development of motivation and self-regulated in learning.

This study aims to provide information to the education practitioners and policymakers about what factors are there in a learning environment that can encourage student motivation and self-regulation in learning. The information can also be used for teachers in directing and focusing the classroom environment in trying to increase motivation and self-regulatory learning strategies necessary for success. Based on social cognitive learning theory from Albert Bandura, learning is the results of personal, environmental, and behavioral factors. The present study explore several dimensions of the classroom learning environment, including student cohesiveness, teacher support, involvement, investigation, task orientation, cooperation, and equity that is suggested by Velayutham and Aldrige (2013). Personal factors that is explored in this study are self-efficacy, learning goal orientation, and task value.

This study examines evidence regarding how dimensions of the learning environment can enhance or undermine academic motivation. This study also examines theoretical perspectives on learning motivation, namely achievement goal theory, social cognitive theory, and self-determination theory. Previous research suggested that relations among learning environment with self-regulated learning are affected by learning motivation (Kharrazi \& Kareshki, 2010). In other words, this study also examines learning motivation as mediating variable on the relationship between learning environment and self-regulated learning especially effort regulation.

Previous research states that the factors affecting self-regulated learning is self-efficacy (e.g., Schunk, 1989; Pintrich \& De Groot, 1990; Pintrich \& Garcia, 1991), goal orientation (e.g., Nicholls, 1984; Pintrich \& De Groot, 1990; Pintrich \& Garcia, 1991; Ames, 1992; Pintrich, 1999), and task value (e.g., Eccles \& Wigfield, 2002). According to Schunk and Zimmerman (1997), goal orientation and self-efficacy is the mediating variables that affect the relationship between perceived learning environment and self-regulated learning. Therefore, the relationship between perceived learning environment, goal orientation, self-efficacy, and self-regulated learning is not a simple one, but it involves direct and indirect effects and relations. However, I have chosen structural equation modeling to study involved causal relations.

\section{Literature Review and Hypothesis Development}

\subsection{Learning Environment}

What happens in the classroom such as the nature of the teaching and learning and interaction experienced students will have an impact on the results achieved. Although the learning environment is a subtle concept, but some issues related to the achievement of such assessment and examination students can affect students' learning. Environment and interaction between individuals that exist in the environment are powerful determinants of the individual behavior. In such environments besides there are personal relationships, there is also a business for their personal development and system management.

Personal relationships focus on the type and strength of relationships between individual and environment. Personal development emphasizes on self-development and self-enhancement. System management evaluates and hold control of, and responsive to change. This study uses multiple dimensions of learning environment like in research Velayutham and Aldrige (2013) namely student cohesiveness, teacher support, involvement, investigation, task orientation, cooperation, and equity. Previous research shows that students who perceive teachers as an affirmation of the learning goals are more likely to use self-regulatory strategies in learning (Urdan \& Schoenfelder, 2006).

According to Ryan, Pintrich, and Midgley (2001), students do not learn on their own, but requires the presence of peers and teachers. Teachers help to condition the classroom social environment by creating norms and regulations for students' social behavior in the classroom and provide explicit messages about the interaction with colleagues. Type assignment given by the teacher also can encourage or dissuade cooperation and sharing capabilities. In addition, the engagement, the willingness of students to perform tasks, the urge to seek a variety 
of things unknown, and get the same treatment is also a condition of learning environment created by students and teachers.

According to Young (2005), learning environment can affect self-regulated learning and learning motivation. Results of previous studies have consistently shown that the learning environment affect students' academic self-efficacy and students' self-efficacy beliefs in academic performance and affect the improvement of learning environment and students' achievement (Velayutham \& Aldrige, 2013). Dorman and Fraser (2009) stated that improvement of the classroom learning environment has the potential to improve students' outcomes. Students will learn better when they perceives that their classroom environment positively. Patrick and Ryan (2003) found that the classroom learning environment is an overarching construct that is comprised of different, but related dimensions. Urdan and Schoenfelder (2006) states that key characteristics of classroom learning environment will encourage students' motivation.

Effect of psychosocial aspects of the classroom learning environment (such as teacher support, student cohesiveness, involvement, investigation, task orientation, cooperation, and equity) in the motivation that includes students' academic self-efficacy, task value, and learning goal orientation would have some implications for students outcomes (Aldrige, Afari, \& Fraser, 2013). Therefore, the influence of psychosocial learning environment on students' learning goal orientation, task value, and self-regulation still requires further research. Based on the social cognitive theory, relevant aspect of the learning environment can affect both student motivation and self-regulation. Based on these discussions, the study predicts that all dimensions of the learning environment would have a positive correlation and influence on students' learning motivation and students' self-regulation in effort regulation.

\subsection{Motivation in Learning}

The biggest challenge of teachers at the beginning of this century is to provide a learning environment that encourages students' motivation to learn. Motivation is part of a complex in human psychology and behavior that affect how individuals choose to invest the time, how much energy is used to perform a specific task, how they think and feel his duties, and how long they perform their duties (Urdan \& Schoenfelder, 2006). More recently, many studies use social-cognitive perspective in examining the motivation (Dweck \& Leggett, 1988). Based on this perspective, the motivation arises from the reaction between individuals within the social context of the school and classroom.

There are several theoretical perspectives that use classroom effects on students' motivation, namely the achievement goal theory, self-determination theory and social cognitive theory. Achievement goals theory indicates that the quality of students' motivation in the classroom depends on the class situation (Ames, 1992). Self-determination theory indicates that students have three basic needs items, namely need for competence, for autonomy, and relatedness for which can be found in the classroom (Deci \& Ryan, 1985). Meanwhile, social cognitive theory suggested that students' beliefs about the likelihood of their success is determined on specific tasks, their competence, and wishes that the results can be achieved related to his participation in a given task which will increase the desire to be bound by the task (Pajares, 1996). The three theories emphasize the importance of appropriately challenging academic work for students and stressed the importance of a sense of ownership over the learning process (Urdan \& Schoefelder, 2006). Meanwhile, Young (2005) states that the cognitive evaluation theory also explains effect of learning environment on learning motivation. Cognitive evaluation theory tests the perceived competency (self-efficacy) and task value affects the motivation. Cognitive evaluation theory is sub-theory of self-determination theory in which a supportive environment will encourage the emergence of intrinsic motivation. This will encourage the students' self-regulated learning.

Previous research has proved that motivated students are the key to learning (Pajares, 2001; 2002). Meanwhile, to improve the academic achievement students must increase class attendance, participation in class activities, actively asking questions and express their opinions, participate in learning groups, and increase learning hours. Results of previous studies have also suggested that students' motivation plays an important role in the process of conceptual change, critical thinking, learning strategies, and learning achievement (Glynn, Taasoobshira, \& Brickman, 2007). According to Zimmerman (2002), there are three components of the motivation that was consistently observed and closely associated with learning (i.e., learning goal orientation, task value, and self-efficacy). Velayutham and Aldrige (2013) that examines the influence of motivational construct (learning goal orientation, task value, and academic self-efficacy) on students' self-regulation states that there is no motivational effect of these constructs in students' self-regulated learning. Based on the theoretical and research ground discussed, this research envisaged that students' motivational beliefs in learning would have a positive correlation and influence on students' self-regulation in learning. 


\subsubsection{Learning Goal Orientation}

One of the most important theories to explain the students' learning motivation is achievement goal theory, which includes learning goal orientation and performance goal orientation (Ames, 1992). Learning goal orientation includes the students' goal in developing competence and focusing on learning, understanding, and performing tasks. Performance goal orientation indicates the purpose of demonstrating competence and managing the impressions of others. Ames and Archer (1988) found that motivation model of high achievement students called the perceived goal orientation can motivate students in self-regulation, long-term involvement and interest in learning.

Learning goal orientation indicates a desire to achieve results in accordance with the actual process of learning, such as feel satisfied and have the competence or the true intellectual development. Learning goal orientation associated with persistence and strategies used in the learning process. Learning goal orientation is associated with persistence when encountering difficulties and obstacles, the desire to try a variety of strategies to solve problems and enjoy the challenge (Eppler \& Harju, 1997). The underlying learning goal orientation is the belief that the effort is a way to be successful and be able to improve. Schraw, Horn, Thorndike-Christ, and Bruning (1995) found that students with a strong learning goal orientation will perform better than students with weak learning goal orientation. Based on the results of previous studies, students' learning goal orientation will affect positive learning outcomes, including students' achievement (Kaplan \& Maehr, 1999; 2007).

Meanwhile, performance goal orientation is characterized by a desire to elicit good judgment and avoid negative evaluation. It shows her election to the easier task that can guarantee success, perseverance is low, and the deteriorating performance when facing obstacles, increased anxiety on performance, and avoidance of duty. According to Kaplan and Maehr (2007), in many cases, when students are less competent and do not perform effectively, it can interfere with the performance goal orientation. Urdan and Schoenfelder (2006) concluded that the performance goal orientation has the potential to reduce both students' motivation and achievement.

Learning goal orientation was linked to the use of learning strategies, higher self-efficacy, and higher level of performance (Pintrich \& Garcia, 1991). Furthermore, students' self-regulation and goal orientation are interwoven constructs that influence student learning (Wolters, Yu, Pintrich, 1996). Learning goal orientation is also an important personality predictor of self-regulated learning (Vandewalle, 2001). Individuals with learning goal orientation tend to focus on self-improvement and explore their learning.

Kaplan and Maehr (2007) also proved that learning goal orientation is a key predictor of the students' motivated behavior. Learning goal orientation represents a concern with developing competence and skills. Learning goal orientation also increases learning time students, the desire of students facing difficulties, and students' engagement in learning. Wigfield and Cambria (2010) reviewed the goal orientation concluded that the motivation theorists agree learning goal orientation benefits for students and recommends that learning goal orientation is focused on school. Based on theoretical and empirical research evidence, learning goal orientation can be assumed as a key component in a student's learning motivation (Velayutham, Aldrige, \& Fraser, 2012). Based on these discussions, this study predicts that learning goal orientation would have a positive correlation and influence on students' self regulation in learning.

\subsubsection{Task Value}

Task value is a students' perception of a valuable or useful of course (Lynch, 2010). Task value is defined as an incentive to be bound in academic activities that include the perceived importance, usefulness, and interest (Wigfield \& Eccles, 1992). Definition of task value was based on the quality of the different tasks and how the quality affects the desire of students to perform tasks. Task value also a perceived value in a particular task (Pintrich \& Garcia, 1991). Academic task value beliefs are integral elements that make up students' motivation to learn (Pintrich \& De Groot, 1990). Task value construct is originated from expectancy value theory (Minnaert, 1999). Expectancy value theory emphasizes the fundamental role of task value to the students' expectation of success, achievement-related choices, and academic performance (Eccles \& Wigfield, 2002). Task value is characterized as personal characteristics based on expectancy-value motivation model (Wigfield, 1994). Tuan, Chin and Shieh (2005) stated that the task value also affects students' attitude toward learning and accomplishment or achievement.

Perception of the task value and self-efficacy are usually positively correlated and are effective predictors of academic outcomes (Bong, 2004). Previous research suggests that task and is strongly associated with students' self-regulatory strategies (Pintrich \& De Groot, 1990; Wolters et al., 1996). Students who convinced that the learning activities is important, appealing, and useful tend to be more engaged cognitively to learn, put in greater effort, and more persistent in completing the task of learning (Wolters \& Rosenthal, 2000; Schunk \& 
Zimmerman, 2007). Pajares and Valiante (2001) stated that task value along with self-efficacy, achievement goals, academic self-concept, and academic performance is positively associated with self-regulated learning strategy. Based on these discussions, this study predicts that the task value would have a positive correlation and influence on students' self regulation in learning.

\subsubsection{Self-Efficacy}

Research that examines the role of motivation in self-regulated learning to use self-efficacy is used to predict the behavior of these learning (Usher \& Pajares, 2008). Self-efficacy is defined as students' beliefs about competencies to perform tasks (Zusho, Pintrich, \& Coppola, 2003). Social cognitive theory states that in the absence of an individual's belief that they were able to achieve the expected results, they only have little incentive to work. Because self-efficacy is a pivotal construct that can affect students' engagement in learning, so many studies that use it as a motivational construct. Self-efficacy was found to affect the performance during the learning task (Shell \& Husman, 2008).

According Ferla, Valcke and Schuyton (2010), self-efficacy for self-regulated learning shows students' self-perceived capability in carrying out the self-regulated learning strategies. Self-efficacy is derived from social cognitive theory and important in learning achievement (Pajares, 1996). According to social cognitive theory, students are encouraged to learn when they believe they are capable of producing the desired outcomes (Bandura, 1986). Individuals with higher learning goal orientation in general, have higher self-efficacy so that it can motivate individuals (Dweck \& Leggett, 1988). Self-efficacy is usually described as a special task and an important process in self-regulation (Wolters \& Pintrich, 1998).

Self-efficacy has been getting a lot of attention in educational research and in showing its influence on students' academic achievement. Previous research consensus view is that there is a positive relationship between students' self-efficacy beliefs and their self-regulation in learning (e.g., Zimmerman, 2000; Sungur, 2007). Students who have high self-efficacy typically work harder, often evaluate progress achieved, and engaged in self-regulatory strategies that encourage their success in school. Conversely, individuals with low self-efficacy beliefs tend to show more academic maladaptive behaviors such as having anxiety, quickly surrendered when confronted with difficulties, and less interested in coming to school and on achievement (Usher \& Pajares, 2008). Previous research suggests that self-efficacy associated with achievement and engagement in activities (Pajares, Britner, \& Valiante, 2000; Kupermintz, 2002). Efficacious learners tend to be more willing to be bound in duty (Pajares \& Miller, 1994), set challenge goals, and maintains a strong commitment to achieve these goals (Bernacki, Nokes-Malach, \& Aleven, 2015). Self-efficacy beliefs are a motivational construct that arise from the learning process.

According Pajares (2002), self-efficacy is closely linked to the students' self-regulated learning. Murphy and Alexander (2001) state that self-efficacy consistently were the constructs of motivation and show consideration or assessment of the individual's ability to perform the task. Results of previous studies also showed a positive relationship between self-efficacy beliefs and academic performance and persistence of learning (Zimmerman, Bandura, Martinez-Pons, 1992). Self-efficacy is an important predictor for successful use of self-regulated learning skills and strategies (Fadlelmula, Cakiroglu, \& Sungur, 2015). Based on these discussions, this study predicts that self-efficacy in learning would have a positive correlation and influence on students' self regulation in learning.

\subsection{Self-Regulation}

Eccles and Wigfield (2002) define self-regulated learning as an activity of the individual in the learning process in cognitive, motivational, and behavioral. Self-regulation is an individual's ability to control and regulate the achievement of objectives. Self-regulation in learning is also an important result of the schooling process and as a key determinant of students' academic achievement. Successful learners can organize their work, set goals, seek assistance when needed, manage time, and use the work strategies effectively (Zimmerman \& Martinez-Pons, 1988; Zimmerman \& Bandura, 1994; Zimmerman, 2000). Self-regulation is a tendency to maintain focus and efforts toward the achievement of goals.

Self-regulated learning is the ability to understand and control the learning environment (Schraw, Crippen, \& Hartley, 2006). To do so, individuals should set goals, choose a strategy that helps achieve goals, implement the strategy, and monitor progress towards the goals (Schunk, 1996).

Self-regulated learning is also an active process in which people learn through monitoring, regulating, and controlling towards their cognition, motivation, and behavior that is directed and constrained by their goals and the contextual features in the environment (Pintrich, 2000). A key assumption in the model of self-regulation is 
the students' motivation that plays an important role in self-regulation (Lichtinger \& Kaplan, 2015). Achievement goal theory can relate between motivation and self-regulation.

Self-regulation is a key element necessary to build learning skills. Zimmerman (2008) asserts that influence learning environment on students' self-regulated learning still to be investigated further. Research results of Pintrich (2003) showed that students who are more academically motivated show higher self-regulation in learning. Results of previous studies have also shown that students who are self-regulated gain greater academic achievement (e.g., Guthrie, McRae, \& Klauda, 2007; Dignath, Buettner, \& Langfeld, 2008). According to Wolters and Pintrich (1998), the higher the task value and self-efficacy, the higher the regulatory strategy that used. According to Zimmerman (2008), self-regulated learning theory posits several motivating factors that influence self-regulatory in learning, i.e., self-efficacy, goal orientation, and interest. Based on these discussions, this study predicts that the learning environment, learning goal orientation, task value, and self-efficacy in learning would have a positive correlation and influence on students' self regulation in learning.

\section{Research Method}

\subsection{Participants and Procedure}

This research was conducted in the undergraduate program on business, management, and economics in Yogyakarta and Bandung. Yogyakarta and Bandung are two cities that have different characteristics. Yogyakarta is a student city or a university town, while Bandung is a trade city. Income per capita in both Cities is not too much different. However, because of the title of the two cities led to both cities have differences in the characteristics of learning and its students.

This study used students in both cities as respondents. Selection of setting the research was based on previous research which states that self-regulated learning research is mostly done in the academic field. Students in business, economics, and management programs selected for the study because the students of business, management, and economics require individual who has a high learning motivation and high self-regulatory in running its business. Entrepreneurship requires high motivation and self-regulation is the hidden curriculum in this program. Students will perform better when they have motivation, feeling engaged in learning and being-able to perform learning tasks independently.

This study aims to examine the relationship between learning environment such as student cohesiveness, teacher support, involvement, investigation, task orientation, cooperation, and equity and motivation variables that include learning goal orientation, task value, and self-efficacy, and self-regulated learning. This study aims to examine the mediating role of the three dimensions of motivational beliefs on the relationship between learning environment and self-regulated learning.

This study used survey method with questionnaires distributed by researcher to respondents. The questionnaire was distributed to individual data collection on respondents. The selected sample was purposive sampling method. Samples were students of undergraduate courses on business, management, and economics students who are still active in Indonesia, especially in Yogyakarta and Bandung. The survey was conducted about three months. According to Cooper and Schindler (2008), Neuman (2006), and Sekaran and Bougie (2010), methods of questionnaire survey conducted by the researcher is the best method. Another survey methods such as interviews with direct face to face, a questionnaire was sent by correspondence, questionnaires were read out via the telephone, questionnaires via electronic media, or a combination of survey methods are survey methods that have many weaknesses or biases.

Research by the individual as the unit of analysis requires the sample to the criteria or specific characteristics. Characteristics of the sample were used to convey the characteristics of the sample relative to the population. Samples intended to be representative of the population. Sample size also affected the accuracy or representation of the population, although a large sample will demonstrate a high degree of confidence or the greatest confidence in the study. The sampling method used in this research is non probability sampling. In this method, the elements in the population did not have the same probability to be selected as the sample (Sekaran \& Bougie, 2010; Cooper \& Schindler, 2008). Non probabilistic sampling technique chosen was purposive sampling. The criteria used to select the sample were students in undergraduate programs are currently active for at least one semester of college in Indonesia. In addition, this study used self-assessment. The sample consisted of 307 students (with a response rate of $76.75 \%$ ) out of 400 students. Respondents who were students of graduate program on business, management, and economics who was studying in Yogyakarta and Bandung receives the survey using a pen and paper. Respondents believed anonymity and complete the survey during their activity in campus. 
In this study, I first screened the data for missing respondents. I then used exploratory factor analysis to assess construct validity and use internal consistency with Cronbach's alpha. I then used confirmatory factor analysis to assess the measurement items through examination convergent validity and discriminant validity. Convergent validity assesses whether a score of one criterion relates strongly and measure the dimensions or the construct. This study used a reliability test items for each measure and composite reliability for each construct. Regarding the item reliability of each measure, loading factor suggested by Hair, Black, Babin, Anderson, \& Tatham (2006) of more than 0.7. Meanwhile, the composite reliability of each construct using alpha coefficient of more than 0.7 as suggested by Hair et al. (2006) as a criterion of adequacy reliability. Furthermore, discriminant validity assesses differences constructs studied empirically. Discriminant validity testing can be done by loading of an item for a construct should be greater than the loading of an item for other constructs in the models.

\subsection{Measures}

The current study used self-report questionnaires. The instrument was designed for the unit of analysis at the individual level. Each of the respondents in this study were asked to complete eleven measurements items, namely student cohesiveness, teacher support, involvement, investigation, task orientation, cooperation, and equity which are include in learning environment variable, learning goal orientation, self-efficacy, and task value which are include in learning motivation, and self-regulation in learning especially effort regulation. The questionnaire regarding learning environment, learning motivation, and self-regulation in learning especially effort regulation are taken and developed by the researchers before, namely Velayutham and Aldrige (2013). The questionnaire was adopted with slight modifications to fit with local needs of research in Indonesia. This modification was associated with changes in the questionnaire by using Bahasa Indonesia.

All scales measured by Likert scale with five point Likert scale starting from the score from 1 indicating that strongly disagree to 5 that indicating strongly agree. This study used content validity and construct validity. Content validity examines items of questionnaires that measure a concept and reflects how well the dimensions and the elements described (Sekaran \& Bougie, 2010). Content validity is carried by discussing all items in questionnaires with experts on organizational behavior and educational psychology. Measuring instrument or questionnaire was then tested on 30 respondents who were students who had similar characteristics to the targeted population as suggested by Sekaran and Bougie (2010). Students provide suggestion regarding the sentence in the questionnaire to be easily understood.

Construct validity examines how well the results obtained from the use of questionnaires fit the theories (Sekaran \& Bougie, 2010). Construct validity was conducted by examining the question of existing items using factor analysis with the rotation and loading factor of at least 0.5 as suggested by Hair et al. (2006). Furthermore, this study also examines the consistency and stability of the measuring instrument. This study used the internal consistency with Cronbach's alpha to demonstrate the reliability of measuring instruments. Before examining structural models with Structural Equation Modeling (SEM) with AMOS program, this study examine the relationship and influence among all variables using correlation. This study also used linear regression to examine the direct effect of all independent variables (student cohesiveness, teacher support, involvement, investigation, task orientation, cooperation, equity, learning goal orientation, task value, and self-efficacy) on the dependent variables (self-regulation in learning). Furthermore, this research using independent sample t-test to test differences between Bandung and Yogyakarta in student cohesiveness, teacher support, involvement, investigation, task orientation, cooperation, equity, learning goal orientation, task value, self-efficacy, and self-regulation in learning.

\section{Results}

\subsection{Validity and Reliability Analysis}

This study used questionnaires developed by previous researchers to translate from the original language into Bahasa Indonesia. This study used factor analysis to examine the construct validity. To further simplified the interpretation and found a simpler structure, this study used a technique of orthogonal and varimax rotation. Factor analysis is also performed on the construct being investigated. Extraction executed and each eigenvalue factor greater than one will be adopted. Varimax rotation performed to reveal each variable. Recorded using loading factor above 0.50 as suggested by Hair et al. (2006) which is referred to as the construct validity of the test results are practically significant. Factor analysis conducted to test the construct validity. Loading factor for items questionnaires used in this study recorded between 0.503 and 0.840 . Given all of the items are extracted 0.5 , there are some items that turned out to be deleted because it is declared invalid. Eligible items in construct validity based on the factor analysis then tested for reliability.

Furthermore, to assess the reliability of the questionnaire of all variables tested internal consistency with 
Cronbach alpha values. Cronbach alpha values of reliability tests measuring instrument in this study resulted in a score of 0.746 for student cohesiveness, 0.810 for teacher support, and 0.828 for involvement, 0.854 for investigation, 0.844 for task orientation, 0.856 for cooperation, 0.868 for equity, 0.918 for learning goal orientation, 0.886 for task value, 0.869 for self-efficacy, and 0.857 for self-regulation in learning. Based on the results of testing the reliability of all variables are stated that the reliability of the measuring instrument was far above of the cut-off line reliability as recommended by Hair et al. (2006).

\subsection{Descriptive Statistics}

This current study uses a series of statistical analysis of the relationship between all the constructs or research variables by using correlation analysis. Correlations among the seven dimensions of learning environment (student cohesiveness, teacher support, involvement, investigation, task orientation, cooperation and equity) are significantly positive. Correlations among three dimensions of learning motivation (learning goal orientation, task value, and self-efficacy) are significantly positive. Correlations between seven dimensions of learning environment and self-regulation in learning as well as between the three dimensions of motivation in learning and self-regulation in learning are also significantly positive. Standard deviation, reliability scale, and the correlations between all study variables are presented in Table 1 .

Based on Table 1, the mean of eleven variables are high (mean between 3.4576 and 4.3237) and a are relatively small standard deviation. In addition, all correlations obtained are not too strong. Furthermore, this study used 162 students from Bandung and 145 students from Yogyakarta.

Table 1. Mean, Standard Deviation, and Inter correlations among All Variables

\begin{tabular}{|c|c|c|c|c|c|c|c|c|c|c|c|c|c|c|}
\hline & Mean & SD & $\alpha$ & 1 & 2 & 3 & 4 & 5 & 6 & 7 & 8 & 9 & 10 & 11 \\
\hline Std. Cohesion & 3.7231 & 0.4707 & 0.746 & 1.000 & $0.250^{*}$ & * $0.293 * *$ & $* 0.327 * *$ & *0.247** & $* 0.347 * *$ & $* 0.254 * *$ & $0.229 * *$ & $0.300^{* *}$ & $0.275^{* *}$ & $0.232 * *$ \\
\hline Teach. Support & 3.5444 & 0.4998 & 0.810 & & 1.000 & $0.536^{* *}$ & * $0.414 * *$ & * $0.285^{* *}$ & * $0.416^{* *}$ & * $0.507 * *$ & $0.310^{* *}$ & $0.368 * *$ & $0.356^{* *}$ & $0.201 * *$ \\
\hline Involvement & 3.5225 & 0.4847 & 0.828 & & & 1.000 & $0.581 * *$ & * $0.294 * *$ & * $0.367 * *$ & * $0.468 * *$ & $0.246^{* *}$ & $0.305^{* *}$ & $0.380 * *$ & $0.244^{* *}$ \\
\hline Investigation & 3.4576 & 0.5403 & 0.854 & & & & 1.000 & $0.361 * *$ & * $0.339 * *$ & * $0.381 * *$ & $0.307 * *$ & $0.365^{* *}$ & $0.364 * *$ & $0.294 * *$ \\
\hline Task Orientation & 4.0806 & 0.4701 & 0.844 & & & & & 1.000 & $0.488 * *$ & $* 0.501 * *$ & $0.531 * *$ & $0.526^{* *}$ & $0.539 * *$ & $0.552 * *$ \\
\hline Copperation & 3.8400 & 0.5351 & 0.856 & & & & & & 1.000 & $0.577 * *$ & $0.346^{* *}$ & $0.434 * *$ & $0.425 * *$ & $0.269^{* *}$ \\
\hline Equity & 3.8656 & 0.5289 & 0.868 & & & & & & & 1.000 & $0.483 * *$ & $0.446^{* *}$ & $0.537 * *$ & $0.321 * *$ \\
\hline Learn. Goal Or. & 4.3237 & 0.4869 & 0.918 & & & & & & & & 1.000 & $0.639 * *$ & $0.568^{* *}$ & $0.517 * *$ \\
\hline Task Value & 4.0509 & 0.5109 & 0.886 & & & & & & & & & 1.000 & $0.630 * *$ & $0.523 * *$ \\
\hline Self-Eff. & 3.8603 & 0.5018 & 0.869 & & & & & & & & & & 1.000 & $0.645^{* *}$ \\
\hline Self-Reg. Learn. & 3.8567 & 0.5463 & 0.857 & & & & & & & & & & & 1.000 \\
\hline
\end{tabular}

Notes: correlation is significant at the 0.01 level (2-tailed)

\subsection{Correlation and Regression Analysis}

Correlation between student cohesion and learning goal orientation is significantly positive $(r=0.229, p<0.01)$, correlation between student cohesion and task value is significantly positive $(r=0.300, p<0.01)$, and correlation between student cohesion and self-efficacy is significantly positive $(r=0.275, p<0.01)$. Correlation between teacher support and learning goal orientation is significantly positive $(r=0.310, p<0.01)$, correlation between teacher support and task value is significantly positive $(\mathrm{r}=0.368, \mathrm{p}<0.001)$, and correlation between teacher support and self-efficacy is significantly positive $(\mathrm{r}=0.356, \mathrm{p}<0.01)$. Correlation between involvement and learning goal orientation is significantly positive $(r=0.246, p<0.01)$, correlation between involvement and task value is significantly positive $(\mathrm{r}=0.305, \mathrm{p}<0.01)$, and correlation between involvement and self-efficacy is also significantly positive $(\mathrm{r}=0380, \mathrm{p}<0.01)$.

Furthermore, correlation between investigation and learning goal orientation is significantly positive $(r=0.307$, $\mathrm{p}<0.01)$, correlation between investigation and task value is significantly positive $(\mathrm{r}=0365, \mathrm{p}<0.01)$, and correlation between investigation and self-efficacy is also significantly positive $(r=0.364, p<0.01)$. Correlation between task orientation and learning goal orientation is significantly positive $(r=0.531, p<0.01)$, correlation between task orientation and task value is significantly positive $(\mathrm{r}=0.526, \mathrm{p}<0.01)$, and correlation between task orientation and self-efficacy is also significantly positive $(r=0.539 \mathrm{p}<0.01)$.

Meanwhile, correlation between cooperation and learning goal orientation is significantly positive $(\mathrm{r}=0.346, \mathrm{p}<$ 
$0.01)$, correlation between cooperation and task value is significantly positive $(\mathrm{r}=0.434, \mathrm{p}<0.01)$, and correlation between cooperation and self-efficacy is significantly positive $(r=0.425, p<0.01)$. Correlation between equity and learning goal orientation is significantly positive $(r=0.483, p<0.01)$, correlation between equity and task value is significantly positive $(\mathrm{r}=0.446, \mathrm{p}<0.01)$, and correlation between equity and self-efficacy is also significantly positive $(\mathrm{r}=0.537, \mathrm{p}<0.01)$. The same thing can be seen in the correlation between learning goal orientation and self-regulation learning is also significantly positive $(r=0.517, p<0.01)$. Task value is correlated significantly positive with self-regulation in learning $(\mathrm{r}=0.523, \mathrm{p}<0.01)$ and self-efficacy is correlated significantly positive with self-regulation in learning $(r=0.645, p<0.01)$.

The correlation between student cohesiveness and self-regulated learning is significantly positive $(r=0.207, p<$ $0.01)$, correlation between teacher support and self-regulated learning is significantly positive $(r=0.201, p<$ $0.01)$, correlation between involvement and self-regulated learning is significantly positive $(r=0.244, p<0.01)$, correlation between investigation and self-regulated learning is significantly positive $(r=0.294, p<0.01)$, correlation between task orientation and self-regulated learning is significantly positive $(\mathrm{r}=0.552, \mathrm{p}<0.01)$, correlation between cooperation and self-regulated learning is significantly positive $(r=0.269, p<0.01)$, and correlation between equity and self-regulated learning is significantly positive $(r=0.321, p<0.01)$.

Based on the result of correlation test, all hypotheses about the relationship between two variables were supported. All research constructs in this study were positive correlated significantly. Furthermore, the direct influence of learning environment (student cohesiveness, teacher support, involvement, investigation, task orientation, cooperation, and equity) and learning motivation (learning goal orientation, task value, and self-efficacy) on self-regulated learning was tested using multiple linear regression models. Multiple linear regression testing results are presented in Table 2 .

Table 2. Regression Testing Results

\begin{tabular}{|c|c|c|c|c|c|c|c|}
\hline \multicolumn{8}{|c|}{ Model Summary } \\
\hline \multirow{2}{*}{ Model } & \multirow{2}{*}{$\mathrm{R}$} & \multirow{2}{*}{ R Square } & \multirow{2}{*}{ Adjusted R Square } & \multirow{2}{*}{ Std. Error of the Estimate } & \multicolumn{3}{|c|}{ Change Statistics } \\
\hline & & & & & R Square Change & F Change df1 df2 & Sig. F Change \\
\hline 1 & $.715^{\mathrm{a}}$ & .511 & .495 & .38834 & .511 & $10 \quad 296$ & .000 \\
\hline \multicolumn{8}{|c|}{ a. Predictors: (Constant), SE, SC, TS, IS, KO, LGO, TOR, IN, EK, TV } \\
\hline
\end{tabular}

\begin{tabular}{ccccccc}
\hline \multicolumn{7}{c}{ ANOVA $^{\mathrm{b}}$} \\
\hline & Model & Sum of Squares & $\mathrm{df}$ & Mean Square & $\mathrm{F}$ & Sig. \\
\hline \multirow{3}{*}{1} & Regression & 46.679 & 10 & 4.668 & 30.953 & $.000^{\mathrm{a}}$ \\
& Residual & 44.639 & 296 & .151 & \\
& Total & 91.319 & 306 & & \\
\hline \multicolumn{5}{c}{ a. Predictors: (Constant), SE, SC, TS, IS, KO, LGO, TOR, IN, EK, TV }
\end{tabular}

b. Dependent Variable: SR

\begin{tabular}{|c|c|c|c|c|c|c|}
\hline \multicolumn{7}{|c|}{ Coefficients $^{\mathrm{a}}$} \\
\hline & \multirow{2}{*}{ Model } & \multicolumn{2}{|c|}{ Unstandardized Coefficients } & \multirow{2}{*}{$\begin{array}{c}\text { Standardized Coefficients } \\
\text { Beta }\end{array}$} & \multirow{2}{*}{$\mathrm{t}$} & \multirow{2}{*}{ Sig. } \\
\hline & & B & Std. Error & & & \\
\hline \multirow{6}{*}{1} & (Constant) & .320 & .267 & & 1.197 & .232 \\
\hline & $\mathrm{SC}$ & .010 & .052 & .009 & .189 & .850 \\
\hline & TS & -.050 & .057 & -.046 & -.868 & .386 \\
\hline & IN & .020 & .063 & .018 & .312 & .755 \\
\hline & IS & .033 & .053 & .032 & .612 & .541 \\
\hline & TOR & .327 & .064 & .281 & 5.120 & .000 \\
\hline
\end{tabular}




\begin{tabular}{cccccc}
\hline KO & -.078 & .055 & -.077 & -1.414 & .158 \\
EK & -.129 & .061 & -.125 & -2.099 & .037 \\
LGO & .155 & .065 & .138 & 2.400 & .017 \\
TV & .092 & .065 & .086 & 1.424 & .156 \\
SE & .496 & .064 & .455 & 7.732 & .000 \\
\hline
\end{tabular}

a. Dependent Variable: SR

Based on the results of multiple linear regression test with self-regulated learning as the dependent variable, learning environment (student cohesiveness, teacher support, involvement, investigation, task orientation, cooperation, and equity) and learning motivation (learning goal orientation, task value, and self-efficacy) as independent variables was found that all the independent variables only effect on student self-regulated learning of $49.5 \%$. The other $50.5 \%$ of the self-regulated learning is influenced by many factors that are not tested in this study. Furthermore, when seen from the partial test, it was found that the self-regulated learning was significantly influenced only by task orientation, equity, learning goal orientation, and self-efficacy. Based on the results of regression testing, it can be said that hypothesis about the direct effects of all independent variables on the dependent variable is partially supported.

Meanwhile, of the three constructs of learning motivation, learning goal orientation and self-efficacy are the two constructs that affect self-regulated learning. The desire of students for learning new knowledge, understanding and completing all the necessary tasks, and the desire for improving ability provide an incentive for students to like and complete all the tasks on time. In addition, self-efficacy is the individuals' belief of their ability performing the task and obtaining a satisfactory result will also encourage students to love and complete the task and achieve a satisfactory result.

\subsection{Testing Results of Mediation Model}

This study also explored relationships among variables using structural equation modeling (SEM) with maximum likelihood estimation using analysis of moment structure (AMOS) software. SEM is a combination of exploratory factor analysis and multiple regression analysis. SEM allows the modeling and testing complex models of relationships, including a multitude of hypotheses simultaneously (Kline, 2010). Relationship model testing using SEM is done by measuring the fitness of the model. This study used multiple criteria for fitness of the model, namely the goodness of fit index (GFI), adjusted goodness of fit index (AGFI), chi-square $(\chi 2)$, comparative fit index (CFI), and root mean square error approximation (RMSEA). Relationship model tested in this study presented in Figure 1.

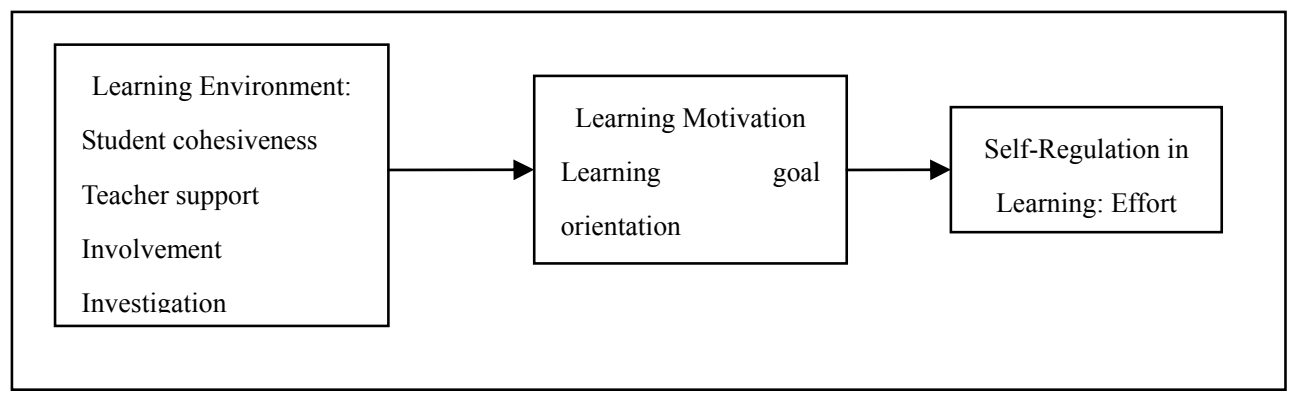

Figure 1. Relationship Model Among Research Variables

Testing mediating model was used to examine the relationship model as in Figure 1. The mediating model was tested using SEM with AMOS software. Testing is done with a two-step approach that is used to increase GFI if in testing the model using a one-step approach indeed found their modification index that is supported by a margin that is too large between the value and the value of GFI AGFI. The test results of structural models simultaneously to test the mediation model using SEM presented in Table 3. 
Table 3. Testing Results of Mediation Model Using SEM

\begin{tabular}{|c|c|c|}
\hline & Standardized Regression Weights & Critical Ratio \\
\hline Learning Goal Orientation $\leftarrow$ Student Cohesiveness & 0.111 & 1.751 \\
\hline Learning Goal Orientation $\leftarrow$ Teacher Support & $0.204 * *$ & 2.477 \\
\hline Learning Goal Orientation $\leftarrow$ Involvement & $0.189 * *$ & 1.991 \\
\hline Learning Goal Orientation $\leftarrow$ Investigation & 0.115 & 1.471 \\
\hline Learning Goal Orientation $\leftarrow$ Task Orientation & $0.592 * *$ & 8.185 \\
\hline Learning Goal Orientation $\leftarrow$ Cooperation & $0.205 * *$ & 2.499 \\
\hline Learning Goal Orientation $\leftarrow$ Equity & $0.236^{* *}$ & 2.856 \\
\hline Task Value $\leftarrow$ Student Cohesiveness & 0.120 & 1.895 \\
\hline Task Value $\leftarrow$ Teacher Support & $0.254 * *$ & 3.096 \\
\hline Task Value $\leftarrow$ Involvement & -0.155 & -1.647 \\
\hline Task Value $\leftarrow$ Investigation & $0.156^{* *}$ & 2.005 \\
\hline Task Value $\leftarrow$ Task Orientation & $0.578 * *$ & 8.040 \\
\hline Task Value $\leftarrow$ Cooperation & -0.044 & -0.547 \\
\hline Task Value $\leftarrow$ Equity & 0.047 & 0.570 \\
\hline Self Efficacy $\leftarrow$ Student Cohesiveness & 0.111 & 1.773 \\
\hline Self Efficacy $\leftarrow$ Teacher Support & 0.125 & 1.540 \\
\hline Self Efficacy $\leftarrow$ Involvement & 0.039 & 0.423 \\
\hline Self Efficacy $\leftarrow$ Investigation & 0.070 & 0.901 \\
\hline Self Efficacy $\leftarrow$ Task Orientation & $0.573 * *$ & 7.995 \\
\hline Self Efficacy $\leftarrow$ Cooperation & -0.100 & -1.243 \\
\hline Self Efficacy $\leftarrow$ Equity & 0.155 & 1.898 \\
\hline Self Regulation $\leftarrow$ Task Value & 0.101 & 1.511 \\
\hline Self Regulation $\leftarrow$ Learning Goal Orientation & $0.139 * *$ & 2.171 \\
\hline Self Regulation $\leftarrow$ Self Efficacy & $0.608 * *$ & 8.834 \\
\hline \multicolumn{3}{|l|}{$\mathrm{GFI}=0.926 \quad \mathrm{df}=10$} \\
\hline \multicolumn{3}{|l|}{$\mathrm{AGFI}=0.512$} \\
\hline \multicolumn{3}{|l|}{ Chi-square $=118.318$} \\
\hline $\mathrm{CFI}=0.921$ & & \\
\hline
\end{tabular}

Table 3 shows the large differences between GFI and AGFI values. This suggests a possible modification of the model. Researchers should analyze the modification index. When index modification indicates possible modification of the model, the researcher has to look at the theoretical framework used. If the theory supports the modification of the model, the researcher can modify the relationship model. The results of modification model presented in Table 4

Table 4. Modification of Testing Results of Mediation Model Using SEM

\begin{tabular}{|c|c|c|}
\hline & Standardized Regression Weights & Critical Ratio \\
\hline Learning Goal Orientation $\leftarrow$ Student Cohesiveness & 0.038 & 0.064 \\
\hline Learning Goal Orientation $\leftarrow$ Teacher Support & 0.021 & 0.278 \\
\hline Learning Goal Orientation $\leftarrow$ Involvement & -0.063 & -0.733 \\
\hline Learning Goal Orientation $\leftarrow$ Investigation & 0.021 & 0.293 \\
\hline Learning Goal Orientation $\leftarrow$ Task Orientation & $0.244 * *$ & 3.297 \\
\hline Learning Goal Orientation $\leftarrow$ Cooperation & $0.167 * *$ & 2.260 \\
\hline Learning Goal Orientation $\leftarrow$ Equity & $0.236^{* *}$ & 3.131 \\
\hline Task Value $\leftarrow$ Student Cohesiveness & 0.083 & 1.249 \\
\hline Task Value $\leftarrow$ Teacher Support & $0.167 * *$ & 1.962 \\
\hline Task Value $\leftarrow$ Involvement & -0.078 & 0.700 \\
\hline Task Value $\leftarrow$ Investigation & 0.153 & 1.879 \\
\hline Task Value $\leftarrow$ Task Orientation & $0.428 * *$ & 5.686 \\
\hline
\end{tabular}




\begin{tabular}{lrr}
\hline Task Value $\leftarrow$ Cooperation & 0.087 & 1.035 \\
Task Value $\leftarrow$ Equity & 0.057 & 0.658 \\
Self Efficacy $\leftarrow$ Student Cohesiveness & 0.048 & 0.810 \\
Self Efficacy $\leftarrow$ Teacher Support & -0.036 & -0.465 \\
Self Efficacy $\leftarrow$ Involvement & 0.157 & 1.789 \\
Self Efficacy $\leftarrow$ Investigation & -0.013 & -0.180 \\
Self Efficacy $\leftarrow$ Task Orientation & $0.282^{* *}$ & 3.759 \\
Self Efficacy $\leftarrow$ Cooperation & -0.061 & -0.822 \\
Self Efficacy $\leftarrow$ Equity & 0.148 & 1.940 \\
Learning Goal Orientation $\leftarrow$ Task Value & $0.540^{* *}$ & 8.130 \\
Self Efficacy $\leftarrow$ Task Value & $0.455^{* *}$ & 6.737 \\
Self Regulation $\leftarrow$ Learning Goal Orientation & $0.168^{* *}$ & 2.626 \\
Self Regulation $\leftarrow$ Self Efficacy & $0.652^{* *}$ & 9.922 \\
GFI $=0.982 \quad$ df $=9$ & & \\
AGFI $=0.865$ & & \\
Chi-square $=32.732$ & & \\
CFI $=0.983$ & &
\end{tabular}

The test results of the structural model with mediating variable simultaneously using SEM also shows some test results are consistent with a direct connection using multiple regression analysis. In the testing simultaneously of relationship models, in addition to the task orientation, cooperation and equity are the two constructs that are positively and significantly affect learning goal orientation. However, the two-dimensional learning environment (cooperation and equity) does not affect self-efficacy. Self-efficacy is affected by task orientation. Meanwhile, task value is influenced by task orientation and teacher support. Furthermore, self-regulated learning is influenced by the learning goal orientation and self-efficacy. In testing of this model, researcher modifies the model based on the index modifications resulting from use traditional SEM model testing. Table 4 is the result of testing a model that has been modified. Such modifications performed on mediating variable, where the task value has no direct effect on self-regulated learning, but the task value affects self-efficacy and learning goal orientation.

The results of this study indicate that learning goal orientation and self-efficacy is a mediating variable on the relationship between learning environment and self-regulated learning. The testing result of structural modeling indicates that the value of goodness of fit index (GFI) is 0.982 , the adjusted goodness of fit index (AGFI) is 0.865 , chi-square $(\chi 2)$ is 32.732 , comparative fit index (CFI) is 0.983 , and the value of root mean square error approximation (RMSEA) is 0.093 . Of the three criteria of suitability models and data, GFI and CFI indicate that the hypothesized model of the sample data fits fairly well (Byrne, 2001). In addition, the chi-square value is small, and RMSEA values approaching 0.1 indicates a mediocre fit.

Furthermore, the election of campus as a place to learn is students' choice. In addition based on the location of residence, students also evaluate the type of campus structure and establish relationships and learning styles base on the social norms of that campus (Lee, Keough, \& Sexton, 2002). According to Lee et al. (2002), the process of social adjustment and campus appraisal reflected in the academic success or failure of the students. This study also examined differences in students' perception of the learning environment, learning motivation, and self-regulated learning between Yogyakarta and Bandung. Based on these test results, between the two cities there was significant difference in the perception of students toward cooperation and equity which is a learning environment. In addition, the students' learning motivation on the dimensions of the task value between students in the city of Yogyakarta and in Bandung there are significant differences.

Table 5. Test Results The difference between Bandung and Yogyakarta

\begin{tabular}{ccccccc}
\hline & & $\mathrm{N}$ & Mean & Standard Deviation & F & Sig. \\
\hline \multirow{2}{*}{ Student Cohesiveness } & Bandung & 162 & 3.7451 & 0.49608 & 1.694 & .194 \\
& Yogyakarta & 145 & 3.6985 & 0.44100 & & \\
Teacher Support & Bandung & 162 & 3.5520 & 0.52193 & .527 & .468 \\
\hline
\end{tabular}




\begin{tabular}{cccccccc}
\hline & Yogyakarta & 145 & 3.5360 & 0.47546 & & \\
Involvement & Bandung & 162 & 3.4878 & 0.52920 & 2.799 & .095 \\
& Yogyakarta & 145 & 3.5612 & 0.42800 & & \\
Investigation & Bandung & 162 & 3.4937 & 0.58771 & 2.792 & .096 \\
& Yogyakarta & 145 & 3.4172 & 0.48067 & & \\
Task Orientation & Bandung & 162 & 4.1042 & 0.47883 & 1.390 & .239 \\
& Yogyakarta & 145 & 4.4053 & 0.46042 & & \\
Cooperation & Bandung & 162 & 3.8125 & 0.58086 & 6.339 & .012 \\
& Yogyakarta & 145 & 3.8707 & 0.47903 & & \\
Equity & Bandung & 162 & 3.8272 & 0.57462 & 5.859 & .016 \\
& Yogyakarta & 145 & 3.9086 & 0.47077 & & \\
Learning Goal Orientation & Bandung & 162 & 4.3657 & 0.49464 & .661 & .417 \\
& Yogyakarta & 145 & 4.2767 & 0.47534 & & \\
Task Value & Bandung & 162 & 4.1335 & 0.54319 & 6.983 & .009 \\
& Yogyakarta & 145 & 3.9586 & 0.45669 & & \\
Self-Efficacy & Bandung & 162 & 3.9298 & 0.51264 & .715 & .398 \\
& Yogyakarta & 145 & 3.7828 & 0.47940 & & \\
Self-Regulated Learning & Bandung & 162 & 3.9198 & 0.53536 & .008 & .931 \\
& Yogyakarta & 145 & 3.9195 & 0.55158 & & \\
\hline
\end{tabular}

\section{Discussion and Implications of Results}

Findings of this study suggest that task orientation is one of the learning environments significantly influence students' learning motivation especially learning goal orientation and self-efficacy. The learning environment consistent with the scale of influence of students' learning motivation and self-regulation in regulation effort is a task orientation. This indicates that awareness of the importance of task completion are given to him and stay consistent like a field of study that have been chosen are the two things needed by students to succeed in the learning process and learning achievement. This is consistent with the findings of Middleton and Midgley (1997) which states that in order for students to succeed in academic tasks, teachers need to apply academic pressures to consistently provide a challenge to students to understand the material studied and completed tasks are complete in class.

Task orientation emphasizes students' accessibility to personal development and self-enhancement (Velayutham \& Aldrige, 2013). In addition to the task orientation, cooperation and equity also affects learning motivation, especially learning goal orientation. Nevertheless, learning environment scale with the greatest influences on students' learning motivation was task orientation. Urdan and Schoenfelder (2006) acknowledge that cooperation with peers is important, because learning in higher education demanding independence for understanding the material presented. Working together, the students can do the task well. Teacher is expected to increase the motivation of students to explain the purpose of each activity and to ensure that students understand what is expected to be achieved.

Self-beliefs of efficacy also affect self-regulation in effort regulation. This is due to the individual to motivate himself, directing its actions with various exercises, forming the belief that they were capable of, the individual to anticipate what will happen in the future, to recognize and realize the goals and thoughts, and turn it into action through self-regulatory mechanisms. Despite all the self-motivational beliefs are important, self-efficacy is the key motivational process for validity in predicting students' effort, persistence, and activity choices (Zimmerman, 1989; Pajares, 1996; Cleary \& Zimmerman, 2004).

Self-efficacy beliefs are an important predictor for successful use of self-regulated learning skills and strategies (Bong, 2001). The results also indicate a relationship between self-efficacy and learning goal orientation. This is due to students with high self-efficacy beliefs tend to set goals that are more challenging and have a stronger commitment to achieving these goals compared to students with low self-efficacy (Bandura, 1993; Schunk, 
2000). Pintrich and Garcia (1991) also suggest that motivational beliefs such as goal orientation and self-efficacy are linked to important ways to the use of cognitive and self-regulatory strategies. Pintrich (1995) stated that learning goal orientation and self-efficacy are major components of self-regulated learning.

The results of this study indicate that the task value is influenced by the task orientation and teacher support. An understanding of the material and coursework and study encourages students to realize the importance of the course material is obtained. Teacher support needed by students in improving the understanding. The results of this study indicate that the task value affect learning goal orientation and self-efficacy. Students who impress the importance of the task will further demonstrate the commitment and involvement in the task and try to do the task.

The finding also showed that task orientation directly and positively influences significant self-regulation in learning based on results of multiple regression analysis. The SEM analysis revealed that task orientation has an effect indirectly on self-regulated learning through mediating role of learning goal orientation, task value, and self-efficacy. In other words, my findings for both multiple regression analysis and SEM analysis suggest that the task orientation significantly influences students' learning goal orientation, self-efficacy, task value, and self-regulation in business, management, and economics learning. Learning goal orientation and self-efficacy is mediating variables in the model of the relationship between the learning environment and self-regulation in effort regulation. This is consistent with the results of previous researchers (e.g., Schunk \& Zimmerman, 1997; Pintrich \& De Groot, 1990; Greene \& Miller, 1996; Pintrich, 1999; Elliot, McGregor, \& Gable, 1994). The results suggest that promoting students 'self-regulation in business, management, and economics learning could be more successful with the prior emphasis on increasing students' motivational beliefs of learning goal orientation and self-efficacy.

Finally, the finding that two of three motivational constructs (learning goal orientation and self-efficacy) were strong predictors of students' self-regulation in business, management, and economics is consistent with previous research (e.g., Miller \& Brickman, 2004; Pintrich \& De Groot, 1990). Contrary to previous research, I did not find and influence of task value on self-regulated learning. Task value was not a significant predictor of self-regulated learning in comparison to self-efficacy and learning goal orientation. Although in current value study task construct and self-regulated learning constructs were correlated significantly. Nevertheless, all three motivational constructs (learning goal orientation, task value, and self-efficacy) are interrelated each other. This finding showed that task value influence self-efficacy and learning goal orientation. Then, self-efficacy and learning goal orientation are the precursors of self-regulated learning.

Differences in perception of students in cooperation and equity as learning environment, and task value as learning motivation influence teaching methods and the material presented in classrooms. Students in Bandung do not need cooperation with their peers. Students in big city like Bandung are individualist. They are also less concerned about the justice received. Moreover, students in big cities like Bandung that was nicknamed as creative cities expecting direct material can be practiced. Meanwhile, students in the city of Yogyakarta perceive learning materials as a way to finish his studies to get a certificate and find a job. Therefore, teachers are expected to prepare instructional strategies in the classroom to adjust the characteristics of the student.

\section{Conclusion}

Task orientation is one aspect of the learning environment significantly influence students learning goal orientation, task value, self-efficacy, and self-regulation in business, management, and economics learning. Task orientation emphasizes students' accessibility to opportunities to personal development and self-enhancement. For encouraging self-regulated learner in college students, educators must first implement strategies that could increase of student motivation toward business, management, and economics learning.

This study intended to examine the relationship between learning environment and self-regulation in effort regulated learning among students as well as investigating the mediating role of academic motivation. The results of this study provide empirical support for the relationship between and within achievement goal theory, cognitive evaluation theory, and self-regulated learning strategies in the context of classroom in higher education. Academic motivation is multiply determined and it is a complex interaction of personal and situational factors. This study reinforces the previous research that the motivation is not only influenced by personal characteristics but also by environmental characteristic especially learning environment. Moreover, this study also strengthen the previous research that learning goal orientation and self-efficacy as motivation variables are strong predictor of self-regulated learning.

This research has several limitations. The main limitation of this cross-sectional study is that it can not examine the mediating variable. So, there is the difficulty in making conclusion without longitudinal analysis. In addition, 
cross-sectional study has a less in-depth analysis. Testing the mediating model is also more appropriate to use longitudinal study. Second, perceived learning environment does not measure objective. Instead, it represents a subjective sense of how learning environment would be available, were it necessary. Thus, future research should include a multidimensional measure of perceived learning environment. The use of self-reported is the third limitation. The use of self-report has the potential bouncing beta effect for increasing effect of one variable to another variable. In addition, the disproportionate sample size indicated resources a smaller sampling of student is the difficulty in making generalization of research result.

\section{References}

Aldrige, J. M., Afari, E., \& Fraser, B. J. (2013). Influence of teacher support and personal relevance on academic self-efficacy and enjoyment of mathematics lessons: A structural equation modeling approach. Alberta Journal of Educational Research, 58(4), 614-633. https://www.researchgate.net/publication/257940853

Ames, C. \& Archer, J. (1988). Achievement goals in the classroom: Students' learning strategies and motivation process. Journal of Educational Psychology, 80(3), 260-267. https://scholar.google.com/scholar_lookup? publication_year $=1988$ \&pages $=260-267$

Ames, C. (1992). Classroom: Goals, structures, and student motivation. Journal of Educational Psychology, 84(3), 261-271.8. http://groups.jyu.fi/sporticus/lahteet/LAHDE_17.pdf

Bandura, A. (1993). Perceived self-efficacy in cognitive development and functioning. Educational Psychologist, 28(2), 117-148. https://www.uky.edu/ eushe2/Bandura/Bandura1993EP.pdf

Bernacki, M. L., Nokes-Malach, T. J., \& Aleven, V. (2015). Examining self-efficacy during learning: Variability and relation to behavior, performance, and learning. Metacognition Learning, 10, 99-117. https://www.researchgate.net/publication/275334397

Bong, M. (2001). Between- and within- domain relations of academic motivation among middle and high school students, self-efficacy, task value and achievement goals. Journal of Educational Psychology, 93, 23-34. https://www.researchgate.net/publication/232531701

Bong, M. (2004). Academic motivation in self-efficacy, task value, achievement goal orientation, and attributional beliefs. The Journal of Educational Research, 97(6), 287-297. http://dx.doi.org/10.3200/ JOER.97.6.287-298.

Byrne, B. M. (2001). Structural Equation Modeling with AMOS: Basic Concepts, Applications, and Programming. New Jersey: Lawrence Erlbaum Associates, Inc.

Cleary, T. J. \& Zimmerman, B. J. (2004). Self-regulation empowerment program: A school-based programming to enhance self-regulated and self-motivated cycles of student learning. Psychology in the School, 41(5), 537-550. https://scholar.google.com/scholar_lookup?publication_year=2004\&pages $=537-550$

Cooper, D. R., \& Schindler, P. S. (2008). Business Research Methods (10th ed.). Singapore: The McGraw Hill Int.

Deci, E. L., \& Ryan, R. M. (1985). The general causality orientation scale: Self-determination in personality. Journal of Research in Personality, 19, 109-134. http://selfdeterminationtheory.org/SDT/documents/1985 DeciRyan_GCOS.pdf

Dignath, C., Buettner, G., \& Langfeldt, H. P. (2008). How can primary school students learn self-regulated learning strategies most effectively? A Meta-analysis on self-regulation training programmer. Educational Psychology Review, 3, 101-129. https://www.researchgate.net/publication/223009722

Dorman, J. P., \& Fraser, B. J. (2009). Psychosocial environment and affective outcomes in technology-rich classrooms: Testing a causal model. Social Psychology of Education, 12, 371-383. DOI:10.1007/s11218-008-9069-8.

Dunn, K. E., Lo, W., Sutcliffe, R., \& Mulvenon, S. W. (2012). Revisiting the motivated strategies for learning questionnaire: A theoretical and statistical reevaluation of the metacognitive self-regulation and effort regulation subscale. Educational and Psychological Measurement, 72(2), 312-331. https://doi.org/10.1177/ 0013164411413461

Dweck, C. S., \& Leggett, E. L. (1988). A social cognitive approach to motivational and personality. Psychological Review, 95(2), 256-273. https://scholar.google.com/scholar_lookup?publication_year=1988 \&pages $=256-273$

Eccless, J. S., \& Wigfield, A. (2002). Motivational beliefs, values, and goals. Annual Review of Psychology, 53, 
109-132. http://outreach.mines.edu/cont_ed/Eng-Edu/eccles.pdf

Elliot, A. J., Mcgregor, H. A., \& Gable, S. L. (1999). Achievement goals, study strategies, and exam performance: A motivation analysis. Journal of Educational Psychology, 91(3), 549-563. https://labs.psych.ucsb.edu/gable/shelly/sites/labs.psych.ucsb.edu.gable.shelly/files/pubs/elliot_et_al._1999. pdf.

Eppler, M. A., \& Harju, B. L. (1997). Achievement motivation goals in relation to academic performance in traditional and nontraditional college students. Research in Higher Education, 38(5), 557-573. https://www.researchgate.net/publication/226162266.

Fadlelmula, F. K., Cakiroglu, E., \& Sungur, S. (2015). Developing a structural model on the relationship among motivational beliefs, self-regulated learning strategies, and achievement in mathematics. International Journal of Science and Mathematics Education, 13, 1355-1375. DOI: 1010.1007/s10763-013-9499-4.

Ferla, J., Valcke, M., \& Schuyton, G. (2010). Judgment of self-perceived academic competence and their differential impact on students' achievement motivation, learning approach, and academic performance. European Journal Psychology Education, 25, 519-536. DOI: 10.1007/s10212-010-0030-9.

Glynn, S. M.; Taasoobshira, G. \& Brickman, P. (2007). Nonscience major learning science: A theoretical model of motivation. Journal of Research in Science Technology, 44, 1088-1107. https://coe.uga.edu/assets/files/ mse/smqii-9-glynn-et-al-2007.pdf.

Greene, B. A. \& Miller, R. B. (1996). Influences on achievement: Goals, perceived ability, and cognitive engagement. Contemporary Educational Psychology, 21(2), 181-192. https://doi.org/10.1006/ceps.1996. 0015 .

Guthrie, J. T., McRae, A., \& Klauda, S. L. (2007). Contributions of concept-oriented reading instruction to knowledge about interventions for motivation in reading. Educational Psychologist, 42(4), 237-250. http://sohs.pbs.uam.es/webjesus/eval_psicopedagogica/lecturas/concept.pdf.

Hair, J. E., Black, W. C., Babin, B. J., Anderson, R. E., \& Tatham, R. L. (2006). Multivariate Data Analysis. (6 ${ }^{\text {th }}$ ed.). New Jersey: Prentice-Hall International Inc.

Kaplan, A. \& Maehr, M. L. (1999). Achievement goals and student well-being. Contemporary Educational Psychology, 24, 330-358. http://condor.depaul.edu/hstein/NALPAK.pdf

Kaplan, A. \& Maehr, M. L. (2007). The contribution and prospects of goal orientation theory. Educational Psychology Review, 19(2), 141-187. DOI: 10.1007/s10648-006-9012-5

Kharrazi, A. \& Kareshki, H. (2010). Environmental perceptions, motivational beliefs, and self-regulating learning by Iranian high school students. Procedia Social and Behavioral Sciences, 5, 2160-2164. DOI: 10.1016/j.sbspro.2010.07.430

Kupermintz, H. (2002). Affective and cognitive factors as aptitude resources in high school science achievement. Educational Assessment, 8, 123-137. http://dx.doi.org/10.1207/S15326977EA0802_03

Lee, R. M., Keough, K. A., \& Sexton, J. D. (2002). Social connectedness, social appraisal, and perceived stress in college women and men. Journal of Counseling and Development, 80, 355-361. https://www.researchgate.net/publication/297933067

Lichtinger, E., \& Kaplan, A. (2015). Employing a case study approach to capture motivation and self-regulation of young students with learning disabilities in authentic educational contexts. Metacognition Learning, 10(1), 119-149. DOI:10.1007/s11409-014-9131-1

Maehr, M. L. \& Midgley, C. (1991). Enhancing student motivation: A schoolwide approach. Educational Psychologist, 26(3), 399-427. http://www.unco.edu/cebs/psychology//kevinpugh/motivation_project/ resources/maehr_midgley91.pdf

Middleton, M. J., \& Midgley, C. (1997). Avoiding the demonstration of lack of ability: An underexplored aspect of goal theory. Journal of Educational Psychology, 89(4), 710-718. https://scholar.google.com/scholar lookup?publication_year=1997\&pages $=710-718$

Miller, R. B. \& Brickman, S. J. (2004). A model of future-oriented motivation and self-regulation. Educational Psychology Review, 19(1), 9-33. DOI: 10.1023/B:EDPR.0000012343.96370.39

Minaert, A. (1999). Motivational and emotional components affecting males and females self-regulated learning. European Journal of Psychology of Education, 14(4), 525-540. DOI: 10.1007/BF03172977 
Murphy P. K. \& Alexander P. A. (2001). A motivated exploration of motivation terminology. Contemporary Educational Psychology, 25(1), 3-53. DOI:10.1006/ceps.1999.1019

Neuman, W. L. (2006). Social Research Methods: Qualitative and Quantitative Approaches. (6 ${ }^{\text {th }}$ ed.). New York: Allyn and Bacon.

Nicholls, J. G. (1984). Achievement motivation: Conception of ability, rejective experience, task choice, and performance. Psychological Review, 91(3), 328-346. https://scholar.google.com/scholar_lookup? publication_year $=1984 \&$ pages $=328-346$

Pajares, F. \& Miller, M. D. (1994). Role of self-efficacy and self-concept beliefs in mathematical problem solving: A path analysis. Journal of Educational Psychology, 86(2), 193-203. DOI: 10.1037/0022-0663.86.2.193

Pajares, F. \& Valiante, G. (2001). Gender differences in writing motivation and achievement of middle school students: A function of gender orientation? Contemporary Educational Psychology, 26(3), 366-381. DOI: 10.1006/ceps.2000.1069

Pajares, F. (1996). Self-efficacy beliefs in achievement settings. Review of Educational Research, 66(4), 543-578. https://www.uky.edu>Pajares1996RER

Pajares, F. (2001). Toward a positive psychology of academic motivation. The Journal of Educational Research, 45, 27-35. http://dx.doi.org/10.1080/00220670109598780

Pajares, F. (2002). Gender and perceived self-efficacy in self-regulated learning. Theory into Practice, 41, 116-125. http://dx.doi.org/10.1207/s15430421tip4102_8

Pajares, F., Britner, S. L., \& Valiante, G. (2000). Relation between achievement goals and self-beliefs of middle school students in writing and science. Contemporary Educational Psychology, 25(4), 406-422. DOI: 10.1006/ceps.1999.1027

Patrick, H. \& Ryan, A. M. (2003). Identifying Adaptive Classrooms: Analyses of Measures of Dimensions of the Classroom Social Environment Paper prepared for the Positive Outcomes Conference, March. https://www.childtrends.org/wp-content/uploads/2013/05/Child_Trends-2003_03_12_PD_PDConfPatRyan. pdf

Pintrich, P. R. \& De Groot, E. V. (1990) Motivational and self-Regulated Learning Components of Classroom Aacdemic Performance. Journal of Educational Psychology, 82(1), 33-40. https://scholar.google.com/ scholar_lookup?publication_year=1990\&pages=33-40

Pintrich, P. R. \& Garcia, T. (1991). Student goal orientation and self-regulation in the college classroom. Advances in Motivation and Achievement: Goals and Self-Regulation Process, 7, 371-402. https://www.researchgate.net/publication/243775205

Pintrich, P. R. (1995). Understanding self-regulated learning. New Directions for Teaching and Learning, 63(1), 3-12. DOI: $10.1002 / \mathrm{tl} .37219956304$

Pintrich, P. R. (1999). The role of motivation in promoting and sustaining self-regulated learning. International Journal of Educational Research, 31, 450-470. https://pdfs.semanticscholar.org/c70b/c7142920b1ea74f1 6e14e0defe40ba4846c5.pdf

Pintrich, P. R. (2000). An achievement goal theory perspective on issue in motivation terminology, theory, and research. Contemporary Educational Psychology, 25(1), 92-104. http://acmd615.pbworks.com/f/ AchievementGoall.pdf

Pintrich, P. R. (2003). A motivational science perspective on the role of student motivation in learning and teaching contexts. Journal of Educational Psychology, 95(4), 667-686. https://ueeval.ucr.edu/teaching practices_inventory/Pintrich_2003.pdf

Ryan, A. M., Pintrich, P. R., \& Midgley, C. (2001). Avoiding seeking help in the classroom: Who and why? Educational Psychology Review, 13(2), 93-114. DOI:10.1023/A:1009013420053

Schraw, G., Crippen, K. J. \& Hartley, K. (2006). Promoting self-regulation in science education: Metacognition as part of a broader perspective on learning. Research in Science Education, 36, 111-139. http://citeseerx.ist.psu.edu/viewdoc/download;jsessionid=EFD19DD3F04C302BD532CA59035B6A30?doi $=10.1 \cdot 1.460 .5291 \& \mathrm{rep}=\mathrm{rep} 1 \&$ type $=\mathrm{pdf}$

Schraw, G., Horn, C., Thorndike-Christ, T., \& Bruning, R. (1995). Academic goal orientations and student 
classroom achievement. Contemporary Educational Psychology, 20, 359-368. DOI: 10.1006/ceps.1995.1023

Schunk, D. H., \& Zimmerman, B. J. (1997). Social origin of self-regulatory competence. Educational Psychologist, 32(4), 195-208. https://www.researchgate.net/profile/Barry_Zimmerman/publication/ 247522502

Schunk, D. H. \& Zimmerman, Barry J. (2007). Influencing Children's Self-Efficacy and Self-Regulation of reading and Writing through Modeling. Reading and Writing Quarterly, 23(1), 7-25. https://pdfs.semanticscholar.org/9a0e/9372d47ddefbbdade8f98d6520b437468113.pdf

Schunk, D. H. (1989). Self-efficacy and achievement behavior. Educational Psychology Review, 1, 173-208. DOI:10.1007/BF01320134

Schunk, D. H. (1996). Goal and self-evaluative influences during children's cognitive skill learning. American Educational Research Journal, 33(2), 359-382. https://www.researchgate.net/publication/280778423

Schunk, D. H. (2000). Coming to terms with motivation constructs. Contemporary Educational Psychology, 25 , 116-119. http://acmd615.pbworks.com/f/MotivationConstructs.pdf

Sekaran, U. \& Bougie, R. (2010). Research methods for Business: A Skill Building Approach. (5th ed.). Singapore: A John Wiley \& Sons, Ltd.

Shell, D. F. \& Husman, J. (2008). Control, motivation, affect, and strategic self-regulation in the college classroom: A multidimensional phenomenon. Journal of Educational Psychology, 100, 443-459. DOI: 10.1037/0022-0663.100.2.443

Sungur, S. (2007). Modeling the relationships among students' motivational beliefs, metacognitive strategy use, and effort regulation. Scandinavian Journal of Educational Research, 51, 315-326. https://www.researchgate.net/publication/248962038

Tuan, H. L, Chin, C. C., \& Shieh, S. H. (2005). The development of questionnaire to measure students' motivation towards science learning. International Journal of Science Education, 27(6), 639-654. http://www.ntcu.edu.tw/chin/file/29.pdf

Urdan, T. \& Schoenfelder, E. (2006). Classroom effects on student motivation: Goal structures, social relationships, and competence beliefs. Journal of School Psychology, 94, 331-349. https://motivationallearningtheories.wikispaces.com/file/view/Urdan+Schoenfelder+2006.pdf

Usher, E. L. \& Pajares F. (2008). Self-Efficacy for Self-Regulated Learning: A Validation Study. Educational and Psychological Measurement, 68(3), 443-463. http://sites.education.uky.edu/motivation/files/2013/08/ UsherPajares2008.pdf

Vandewalle, D. (1997). Development and validation of a work domain, goal orientation instrument. Educational and Psychological Measurement, 57(6), 995-1015. DOI: 10.1177/0013164497057006009.

Velayutham, S. \& Aldrige, J. M. (2013). Influence of psychological classroom environment on students' motivation and self-regulation in science learning: A structural equation modeling approach. Research in Science Education, 43(2), 507-527. https://link.springer.com/content/pdf/10.1007/s11165-011-9273-y.pdf

Velayutham, S., Aldrige, J. M.; \& Fraser, B. (2012). Gender differences in student motivation and self-regulation in science learning: A multi group structural equation modeling analysis. International Journal of Science and Mathematics Education, 10, 1347-1368. DOI: 10.1007/s10763-012-9339-y.

Wigfield, A. \& Cambria, J. (2010). Students' achievement values, goal orientations, and interest: Definitions, development, and relations to achievement outcomes. Developmental Review, 30(1), 1-35. http://scottbarrykaufman.com/wp-content/uploads/2014/03/Wigfield-Cambria-2010.pdf

Wigfield, A. \& Eccless, J. S. (1992). The development of achievement task values: A theoretical analysis. Developmental Review, 12, 265-310. http://rcgd.isr.umich.edu/garp/articles/eccles92g.pdf

Wigfield, A. (1994). Expectancy-value theory of achievement motivation: A developmental perspective. $\begin{array}{lllll}\text { Educational Psychology } & \text { Review, } & \text { 69-77), }\end{array}$ http://maaikerotteveel.pbworks.com/f/Wigfield\%20expectancy\%20value\%20theory\%202000.pdf

Wolters, C. \& Pintrich, P. R. (1998). Contextual differences in student motivation and self-regulated learning in Mathematics, English, and Social studies classroom. Instructional Science, 26(1), 27-47. https://deepblue.lib.umich.edu/bitstream/handle/2027.42/43860/11251_2004?sequence=1 
Wolters, C. \& Rosenthal, H. (2000). The relation between students' motivational beliefs and their use of motivational regulation strategies. International Journal of Educational Research, 33, 801-820. https://pdfs.semanticscholar.org/4bb3/3607b4999eeeb5062731ddbae8f86d8f566f.pdf

Wolters, C., Yu, S. L., \& Pintrich, P. R. (1996). The relation between goal orientation and students motivational beliefs and self-regulated learning. Learning and Individual Differences, 8(3), 211-238. DOI: 10.1016/S1041-6080(96)90015-1

Young, M. R. (2005). The motivational effects of the classroom environment in facilitating self-regulated learning. Journal of Marketing Education, 27(1), 25-40. DOI: 10.1177/0273475304273346

Zimmerman, B. J. (1990). Self-regulated learning and academic achievement: An overview. Educational Psychologist, $25(1), \quad 3-17$. http://itari.in/categories/ability_to_learn/self_regulated_learnin_g_and_academic_achievement_m.pdf

Zimmerman, B. J. \& Bandura, A. (1994). Impact of self-regulatory influences on writing course attainment. American Educational Research Journal, 31, 845-862. https://www.uky.edu/ eushe2/Bandura/Bandura1994 AERJ.pdf

Zimmerman, B. J. \& Martinez-Pons, M. (1988). Construct validation of a strategy model of student self-regulated learning. Journal of Educational Psychology, 80(3), 284-290. http://dx.doi.org/10.1037/0022-0663.80.3.284

Zimmerman, B. J. (1989). A social cognitive view of self-regulated academic learning. Journal of Educational Psychology, 81, 329-339. https://pdfs.semanticscholar.org/e1ff/53e710437e009f06bc264b093a2ba9523879. pdf

Zimmerman, B. J. (2000). Self-efficacy: An essential motive to learn. Contemporary Educational Psychology, 26, 82-91. https://www.researchgate.net/profile/Barry_Zimmerman/publication/222529322

Zimmerman, B. J. (2002). Becoming self-regulated learner: An overview. Theory into Practice, 41(2), 64-70. http://mathedseminar.pbworks.com/w/file/fetch/94760840/Zimmerman\%20-\%202002\%20-\%20Becoming $\% 20 \mathrm{a} \% 20$ Self-Regulated\%20Learner\%20An\%20Overview.pdf

Zimmerman, B. J. (2008). Investigating self-regulation and motivation: Historical background, methodologies developments, and future prospects. American Educational Research Journal, 44(1), 166-183. http://rethinking-precollege-math.wikispaces.com/file/view/Zimmerman+2008+Self+Regulation.pdf

Zimmerman, B. J., Bandura, A., \& Martinez-Pons, M. (1992). Self-Motivation for Academic Attainment: The Role of Self-efficacy Beliefs and personal Goal Setting. American Educational Research Journal, 29(3), 663-677. https://www.uky.edu/ eushe2/Bandura/Bandura1992AERJ.pdf

Zusho, A., Pintrich, P. R., \& Coppola, B. (2003). Skill and will: The role of motivation and cognition in the learning of college chemistry. International Journal of Science Education, 25(9), 1081-1094. http://www-personal.umich.edu/ bcoppola/publications/49.\%20Zusho\%20PAPER.pdf

\section{Copyrights}

Copyright for this article is retained by the author(s), with first publication rights granted to the journal.

This is an open-access article distributed under the terms and conditions of the Creative Commons Attribution license (http://creativecommons.org/licenses/by/4.0/). 